Check for updates

Cite this: RSC Adv., 2018, 8, 38013

Received 21st September 2018 Accepted 26th October 2018

DOI: $10.1039 / c 8 \mathrm{ra07876a}$

rsc.li/rsc-advances

\section{A novel resource utilization method using wet magnesia flue gas desulfurization residue for simultaneous removal of ammonium nitrogen and heavy metal pollutants from vanadium containing industrial wastewater}

\begin{abstract}
Dean Fang, (D) ${ }^{\text {ab }}$ Xuefei Zhang ${ }^{\mathrm{ab}}$ and Xiangxin Xue ${ }^{\star a b}$
In the present study, a novel resource utilization method using wet magnesia flue gas desulfurization (FGD) residue for the simultaneous removal of ammonium nitrogen $\left(\mathrm{NH}_{4}-\mathrm{N}\right)$ and heavy metal pollutants from vanadium (V) industrial wastewater was proven to be viable and effective. In this process, the wet magnesia FGD residue could not only act as a reductant of hexavalent chromium $[\mathrm{Cr}(\mathrm{VI})]$ and pentavalent vanadium $[\mathrm{V}(\mathrm{V})]$, but also offered plenty of low cost magnesium ions to remove $\mathrm{NH}_{4}-\mathrm{N}$ using struvite crystallization. The optimum experimental conditions for $\mathrm{Cr}(\mathrm{VI})$ and $\mathrm{V}(\mathrm{V})$ reduction are as follows: the reduction $\mathrm{pH}=2.5$, the wet magnesia $\mathrm{FGD}$ residue dose is $42.5 \mathrm{~g} \mathrm{~L}^{-1}, t=15.0 \mathrm{~min}$. The optimum experimental conditions for $\mathrm{NH}_{4}-\mathrm{N}$ and heavy metal pollutants removal are as follows: the precipitate $\mathrm{pH}=9.5$, the $n\left(\mathrm{Mg}^{2+}\right): n\left(\mathrm{NH}_{4}{ }^{+}\right): n\left(\mathrm{PO}_{4}{ }^{3-}\right)=0.3: 1.0: 1.0, t=20.0 \mathrm{~min}$. Finally the $\mathrm{NH}_{4}-\mathrm{N}, \mathrm{V}$ and $\mathrm{Cr}$ were separated from the vanadium containing industrial wastewater by forming the difficult to obtain, soluble coprecipitate containing struvite and heavy metal hydroxides. The residual pollutant concentrations in the wastewater were as follows: $\mathrm{Cr}(\mathrm{vl})$ was $0.047 \mathrm{mg} \mathrm{L}^{-1}$, total $\mathrm{Cr}$ was $0.1 \mathrm{mg} \mathrm{L}^{-1}, \mathrm{~V}$ was $0.14 \mathrm{mg} \mathrm{L}^{-1}, \mathrm{NH}_{4}-\mathrm{N}$ was $176.2 \mathrm{mg} \mathrm{L}^{-1}$ (removal efficiency was about 94.5\%) and phosphorus was $14.7 \mathrm{mg} \mathrm{L}^{-1}$.
\end{abstract}

\section{Introduction}

Sulfur dioxide $\left(\mathrm{SO}_{2}\right)$ is one of the primary atmospheric pollutants attributed to the burning of fossil fuels, and the emission of $\mathrm{SO}_{2}$ leads to acid precipitation, vegetation destruction, and airborne particulate matter. ${ }^{1,2}$ Out of all the emission sources of oxysulfide in China, thermal power plants are primarily responsible, and the flue gas desulfurization (FGD) system is the main method used for reducing $\mathrm{SO}_{2}$ because it is a mature method and is widely used by the majority of the thermal power plants. ${ }^{1-4}$ The FGD technologies can be roughly divided into three methods: wet processes, semi-dry processes and dry processes. Of all these methods, the take-up rate of use of wet FGD processes was about $85 \%$ for worldwide use of FGD technology because of its high efficiency and wide applicability. In the past few decades, the wet limestone-gypsum process was the mainstream technology, which had a take-up rate of about $90 \%$ for the reduction of $\mathrm{SO}_{2}$ emissions in China. ${ }^{4-6}$ It is worth noting that the wet magnesia FGD technology has been gradually applied to thermal power

aDepartment of Resource and Environment, Northeastern University, Shenyang, 110819, PR China.E-mail: 123767899@qq.com; xuexx@mail.neu.edu.cn

${ }^{b}$ Liaoning Key Laboratory of Recycling Science for Metallurgical Resources, Shenyang 110819, PR China plants in China. Compared with the conventional wet limestonegypsum process, wet magnesia FGD technology has many merits, such as high and stable desulfurization efficiency, simple and compact flow sheet, low investment and energy consumption. In particular, China has the most abundant reserves of the magnesite mineral, which has encouraged the development of wet magnesia FGD technology. ${ }^{7-9}$

The mechanism of the wet magnesia FGD process is similar to the wet lime-gypsum method. In the wet magnesia FGD process, magnesium hydroxide slurry is used as the $\mathrm{SO}_{2}$ absorbent, which is prepared using an aging treatment of a mixture of magnesium oxide and water at a particular ratio. After removing the dust, the flue gas entered the absorption tower, and the $\mathrm{SO}_{2}$ in the flue gas was subsequently absorbed by small magnesium hydroxide droplets from the spraying system. Therefore, the $\mathrm{SO}_{2}$ in the flue gas could be removed and fixed in the desulfurization slurry because of the formation of low solubility magnesium sulfite. ${ }^{2,7-11}$ After the slurry has reached the saturation absorption, the desulfurization product can be separated from the spent slurry by filtration to form the FGD residue, and the main composition of the FGD residue is magnesium sulfite hydrate.

At present, the main resource utilization method of the wet magnesia FGD residue was recovery of magnesium sulfate using 
forced catalytic oxidation and crystallization. The current research focuses on the development of a low cost and highly efficient catalyst., ${ }^{2,12-14}$ As well as the regeneration of activated magnesia for FGD and regeneration of $\mathrm{SO}_{2}$ for acid making using thermal decomposition of wet magnesia, FGD residue was also an attractive approach. But the oxidation of the magnesium sulfite should be prevented by adding an oxidation inhibitor during the FGD process because of the higher thermal decomposition temperature of magnesium sulfate..$^{\mathbf{8 , 9 , 1 5 , 1 6}}$ Nowadays, the vast majority of the wet magnesia FGD residue is casually stacked without further treatment or discarded after forced aeration oxidation, and this is attributed to the high investment associated with the equipment for the treatment process and the low economic benefit of recycled products.

The wastewater discharged from the sodium roasting vanadium extraction technology is complex, hard to degrade biochemically, has a high pollutant gas concentration, and is a highly hazardous acidic wastewater containing high concentrations of vanadium (V), hexavalent chromium [Cr(vI)] and ammonium nitrogen $\left(\mathrm{NH}_{4}-\mathrm{N}\right) \cdot{ }^{17-20}$ The pollution emission concentration ranges of $\mathrm{Cr}(\mathrm{vI})$, total chromium, vanadium and $\mathrm{NH}_{4}-\mathrm{N}$ in the wastewater were approximately 2500$4500 \mathrm{mg} \mathrm{L}^{-1}, 3000-5000 \mathrm{mg} \mathrm{L}^{-1}, 30-150 \mathrm{mg} \mathrm{L}^{-1}$ and $2000-$ $3500 \mathrm{mg} \mathrm{L}^{-1}$, respectively. According to the national discharge standard of pollutants for the vanadium industry (GB 264522011), the residual concentration of $\mathrm{Cr}(\mathrm{vI})$, total $\mathrm{Cr}, \mathrm{V}$ and $\mathrm{NH}_{4}^{-}$ $\mathrm{N}$ in the wastewater must be below $0.5 \mathrm{mg} \mathrm{L}^{-1}, 1.5 \mathrm{mg} \mathrm{L}^{-1}$, $1.0 \mathrm{mg} \mathrm{L}^{-1}$ and, $40 \mathrm{mg} \mathrm{L}^{-1}$, respectively. In reality, the heavy metal pollutants of the vanadium containing industrial wastewater were treated using chemical reduction precipitation, where the $\mathrm{NH}_{4}-\mathrm{N}$ was treated using air stripping or struvite precipitation. In the traditional treatment progress, a lot of reagents were consumed, such as the reductants for the heavy metal removal, and the magnesium salts for the $\mathrm{NH}_{4}-\mathrm{N}$ removal..$^{5,7}$

In this study, a novel resource utilization of the wet magnesia FGD residue for simultaneous removal of $\mathrm{NH}_{4}-\mathrm{N}$ and heavy metal pollutants from the vanadium containing industrial wastewater is presented. In this process, the wet magnesia FGD residue could not only reduce the $\mathrm{Cr}(\mathrm{VI})$ and $\mathrm{V}$ to $\mathrm{Cr}(\mathrm{III})$ and $\mathrm{V}$ (Iv) which were low in toxicity and easy to separate under neutral conditions, but also offered plenty of low cost magnesium ions for removing ammonium using struvite crystallization. Therefore, the wet magnesia FGD residue could simultaneously remove $\mathrm{V}, \mathrm{Cr}$ and $\mathrm{NH}_{4}-\mathrm{N}$ from wastewater by forming the difficult to obtain, soluble coprecipitate containing struvite and heavy metal hydroxides. Compared with the conventional methods, this technology not only reduced the treatment cost of vanadium containing industrial wastewater and wet magnesia FGD residue, but also achieved the excellent objective of "waste treated by waste".

\section{Materials and methods}

\section{Wet magnesia flue gas desulfurization residue}

The wet magnesia FGD residue used in this work was provided by the Datang Lubei thermal power plant in the Shandong province of China. Because the residue was stacked at a waste landfill site for about three months under natural conditions, the FGD residue could be crushed directly and stored in a plastic valve bag. The chemical composition of the wet magnesia FGD residue was as follows (wt\%): magnesium oxide (MgO): 25.9, sulfite $\left(\mathrm{SO}_{3}{ }^{2-}\right): 23.75$, sulfate $\left(\mathrm{SO}_{4}{ }^{2-}\right): 12.81$, silicon dioxide $\left(\mathrm{SiO}_{2}\right): 3.35$, calcium oxide $(\mathrm{CaO}): 1.56$, chloride $(\mathrm{Cl})$ : 0.72 , carbonate $\left(\mathrm{CO}_{3}{ }^{2-}\right): 6.75$, TFe: 0.23 . The results of the X-ray diffraction (XRD) analysis of the wet magnesia FGD residue are shown in Fig. 1(a), and the peaks of the wet magnesia FGD residue were consistent with those of magnesium sulfate trihydrate $\left(\mathrm{MgSO}_{3} \cdot 3 \mathrm{H}_{2} \mathrm{O}\right.$, JCPDS no. 00-024-0738), magnesium carbonate $\left(\mathrm{MgCO}_{3}\right.$, JCPDS no. 00-008-0479), magnesium sulfate hexahydrate $\left(\mathrm{MgSO}_{4} \cdot 7 \mathrm{H}_{2} \mathrm{O}\right.$, JCPDS no. 00-036-0419), and magnesium sulfate tetrahydrate $\left(\mathrm{MgSO}_{4} \cdot 4 \mathrm{H}_{2} \mathrm{O}\right.$, JCPDS no. 00024-0720). As is shown in Fig. 1(b) and (c), wet magnesia FGD residue consists of irregular particles and its size is about 1-30 $\mu \mathrm{m}$, the chemical element composition of the wet magnesia FGD residue contained oxygen, magnesium, sulfur and a trace of silicon, calcium, ferric iron. The main mineral phases of the wet magnesia flue gas desulfurization residue were $\mathrm{MgSO}_{3}$ $\cdot 3 \mathrm{H}_{2} \mathrm{O}$ and $\mathrm{MgCO}_{3}$ with minor amounts of $\mathrm{MgSO}_{4} \cdot 7 \mathrm{H}_{2} \mathrm{O}$ and $\mathrm{MgSO}_{4} \cdot 4 \mathrm{H}_{2} \mathrm{O}$.

\section{Vanadium containing industrial wastewater}

The wastewater discharged from the sodium roasting vanadium extraction plant was provided by Jianlong Steel Co., Ltd. The concentrations of the main pollutants in the wastewater were as follows: $\mathrm{Cr}(\mathrm{vI})$ was $3800 \mathrm{mg} \mathrm{L}^{-1}$, total $\mathrm{Cr}$ was $4320 \mathrm{mg} \mathrm{L}^{-1}$, V was $75 \mathrm{mg} \mathrm{L}^{-1}, \mathrm{NH}_{4}-\mathrm{N}$ was $3200 \mathrm{mg} \mathrm{L}^{-1}$ and the $\mathrm{pH}=2.14$.

\section{Chemical reagents}

Potassium dichromate $\left(\mathrm{K}_{2} \mathrm{Cr}_{2} \mathrm{O}_{7}\right)$, ammonium metavanadate $\left(\mathrm{NH}_{4} \mathrm{VO}_{3}\right)$, ammonium chloride $\left(\mathrm{NH}_{4} \mathrm{Cl}\right)$, sulfuric acid $\left(\mathrm{H}_{2} \mathrm{SO}_{4}\right)$, diphenylcarbazide $\left(\mathrm{C}_{13} \mathrm{H}_{14} \mathrm{~N}_{4} \mathrm{O}\right)$, magnesium chloride $\left(\mathrm{MgCl}_{2}\right)$, sodium hydroxide $(\mathrm{NaOH})$, sodium phosphate $\left(\mathrm{Na}_{3} \mathrm{PO}_{4}\right)$, acetone $\left(\mathrm{CH}_{3} \mathrm{COCH}_{3}\right)$, Nessler's reagent and sodium potassium tartrate tetrahydrate $\left(\mathrm{KNaC}_{4} \mathrm{H}_{4} \mathrm{O}_{6} \cdot 4 \mathrm{H}_{2} \mathrm{O}\right)$ were purchased from Tianjin Kemiou Chemical Reagent Co., Ltd.

\section{Analysis and detection methods}

The acidity was determined using $\mathrm{pH}$ detectors (PHS-3E). The 1,5-diphenylcarbazide spectrophotometric method was used to determine the $\mathrm{Cr}(\mathrm{vI})$ concentration. The Nessler's reagent spectrophotometry method was used to determine the $\mathrm{NH}_{4}-\mathrm{N}$ concentration. Inductively-coupled plasma-optical emission spectrometry (ICP-OES, Optima 8300DV, PerkinElmer) was used to determine the content of total $\mathrm{Cr}$ ions, $\mathrm{V}$ ions, phosphorus ions and magnesium ions.

The XRD (PW3040/60, Philips) with $\mathrm{Cu} \mathrm{K} \alpha$ radiation $(\lambda=$ $1.54056 \AA$ ) was used to identify the crystalline structure of the wet magnesia FGD residue and the coprecipitate at the sweep rate of $6^{\circ} \mathrm{min}^{-1}$ in the range from $5^{\circ}$ to $90^{\circ}$. The scanning electron microscopy-energy dispersive X-ray spectrometry (SEMEDS, Sigma 500, Zeiss) was used to study the morphology and 
elemental composition of the wet magnesia FGD residue and the coprecipitate.

\section{Experimental procedure}

Batch experiments were performed in a $250 \mathrm{~mL}$ glass beaker on a magnetic heated stirrer at room temperature. The diluted $\mathrm{NaOH}$ solution and diluted $\mathrm{H}_{2} \mathrm{SO}_{4}$ solution were used to control the acidity of the reaction solutions during the course of the experiment. Firstly, a certain amount of wet magnesia flue gas desulfurization residue was added into $200 \mathrm{~mL}$ of wastewater in a glass beaker with continuous stirring, and the $\mathrm{pH}$ of wastewater was controlled at an acidic level until the reduction reaction was completed. Subsequently, a given amount of soluble magnesium and phosphate was added separately into the wastewater to give the desired molar ratio of $\mathrm{Mg}^{2+}, \mathrm{NH}_{4}{ }^{+}$and $\mathrm{PO}_{4}{ }^{3-}$ with constant stirring, and the $\mathrm{pH}$ of the wastewater was then adjusted to an alkaline level. Finally, the vanadium, chromium and ammonium in the vanadium containing industrial wastewater were removed synchronously by forming the difficult to obtain soluble coprecipitate, and the coprecipitate was then dried at $60{ }^{\circ} \mathrm{C}$ before further analysis.

\section{Results and discussion}

The main mechanism of the pollutant removal process

In the conventional sodium salt $\left(\mathrm{Na}_{2} \mathrm{CO}_{3}\right.$ or $\left.\mathrm{NaCl}\right)$ roasting technique, both vanadium and chromium in vanadium bearing slag were oxidized to a high valence state and then transformed into the soluble vanadate and chromate. The roasted products were washed repeatedly in hot water, and the vanadium raw material was obtained from the high concentration vanadium extraction solution using ammonium polyorthovanadate precipitation in acid conditions. ${ }^{7,21-25}$ Therefore, the main existing valences of vanadium and chromium in the wastewater were $\mathrm{Cr}(\mathrm{vI})$ and pentavalent vanadium $[\mathrm{V}(\mathrm{v})]$, respectively. As is already known, the existing forms of $\mathrm{Cr}(\mathrm{vI})$ and $\mathrm{V}(\mathrm{v})$ are closely related to their concentration and $\mathrm{pH}$ of a solution. Therefore, the existing forms of the $\mathrm{Cr}(\mathrm{vI})$ and $\mathrm{V}(\mathrm{v})$ were calculated and determined using the Visual MINTEQ aqueous chemical equilibria software based on the actual heavy metal pollutant's concentration in the wastewater. The speciation distribution of $\mathrm{Cr}(\mathrm{vI})$ and $\mathrm{V}(\mathrm{v})$ were calculated over the range of $\mathrm{pH}=0-14.0$, as shown in Fig. 2. Consequently, it was found that the main existing forms of heavy metal pollutants in vanadium containing industrial wastewater were $\mathrm{Cr}_{2} \mathrm{O}_{7}{ }^{2-}$ and $\mathrm{VO}_{2}{ }^{+} \cdot{ }^{26-28}$

The Eh-pH diagrams of $\mathrm{Cr}-\mathrm{V}-\mathrm{S}-\mathrm{Mg}-\mathrm{H}_{2} \mathrm{O}$ are shown in Fig. 3. Depending on the acidity of the vanadium extraction wastewater $(\mathrm{pH}=2.14)$, the redox potentials of $\mathrm{VO}_{2}{ }^{+}$and $\mathrm{Cr}_{2} \mathrm{O}_{7}{ }^{2-}$ were higher than that of $\mathrm{HSO}_{3}{ }^{-{ }^{5,7,26-31}}$ Consequently, the $\mathrm{VO}_{2}{ }^{+}$ and $\mathrm{Cr}_{2} \mathrm{O}_{7}{ }^{2-}$ could be reduced to $\mathrm{VO}_{2}{ }^{+}$and $\mathrm{Cr}^{3+}$ by $\mathrm{HSO}_{3}{ }^{-}$which is the acidolysis product of wet magnesia FGD residual (main composition is $\mathrm{MgSO}_{3} \cdot 3 \mathrm{H}_{2} \mathrm{O}$ ), as shown in eqn (1)-(3). In addition, the appropriate low $\mathrm{pH}$ condition was conducive to oxidation-reduction reactions because the $\mathrm{H}^{+}$also took part in the reaction. At the same time, a large quantity of $\mathrm{Mg}^{2+}$ was obtained by the dissolution of $\mathrm{MgSO}_{3} \cdot 3 \mathrm{H}_{2} \mathrm{O}, \mathrm{MgCO}_{3}$ [as shown
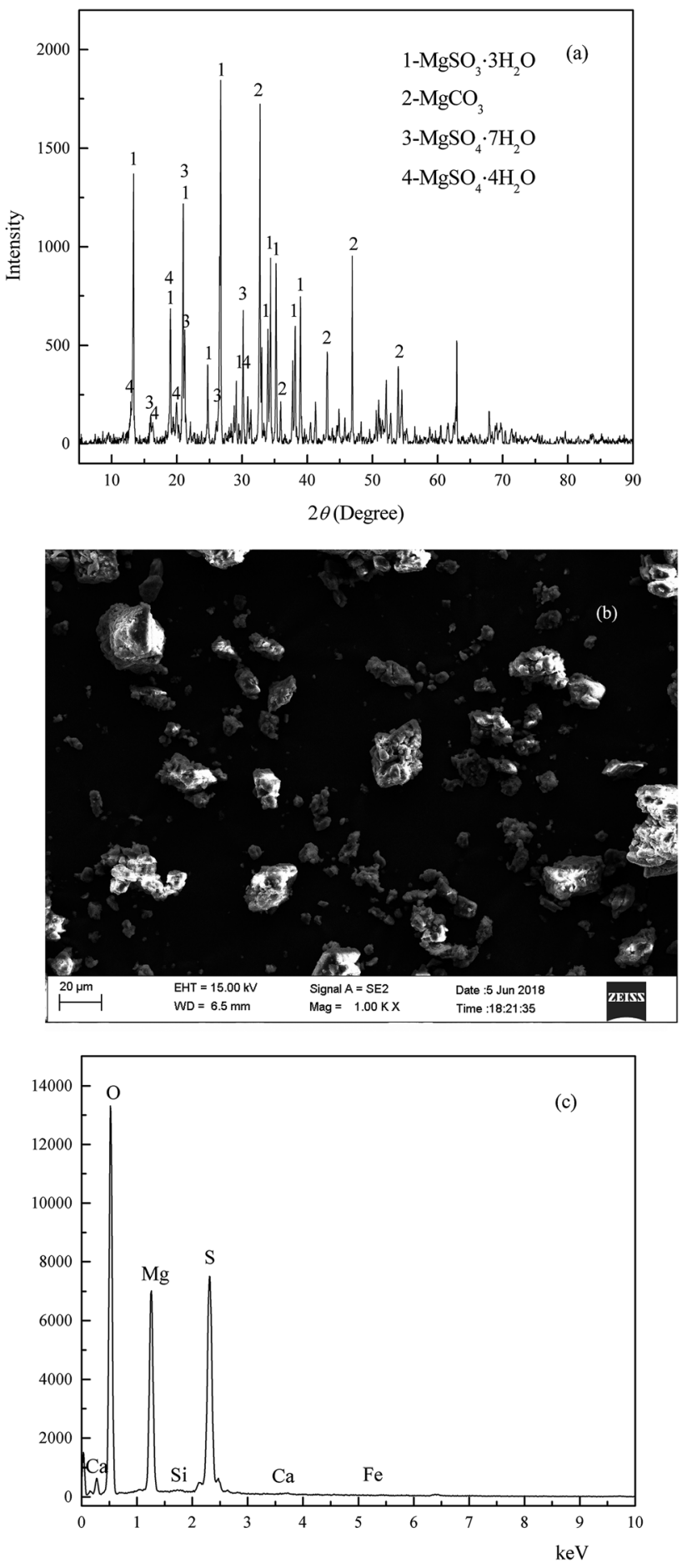

Fig. 1 The XRD (a) and SEM (b) EDS (c) of wet magnesia flue gas desulfurization residue.

in eqn (1) and (4)] and $\mathrm{MgSO}_{4} \cdot n \mathrm{H}_{2} \mathrm{O}$ in the acidic conditions which would be regarded as the low cost magnesium ion source of struvite $\left(\mathrm{MgNH}_{4} \mathrm{PO}_{4} \cdot 6 \mathrm{H}_{2} \mathrm{O}\right)$ crystallization. ${ }^{32-35}$ Following the completion of the reductive reaction, the given amount of soluble magnesium and phosphate were added separately into the wastewater. Then, the $\mathrm{pH}$ of the wastewater was adjusted to alkalinity. Because the $\mathrm{VO}^{2+}, \mathrm{Cr}^{3+}$ and $\mathrm{NH}_{4}{ }^{+}$could be separated synchronously from the wastewater by forming an insoluble 

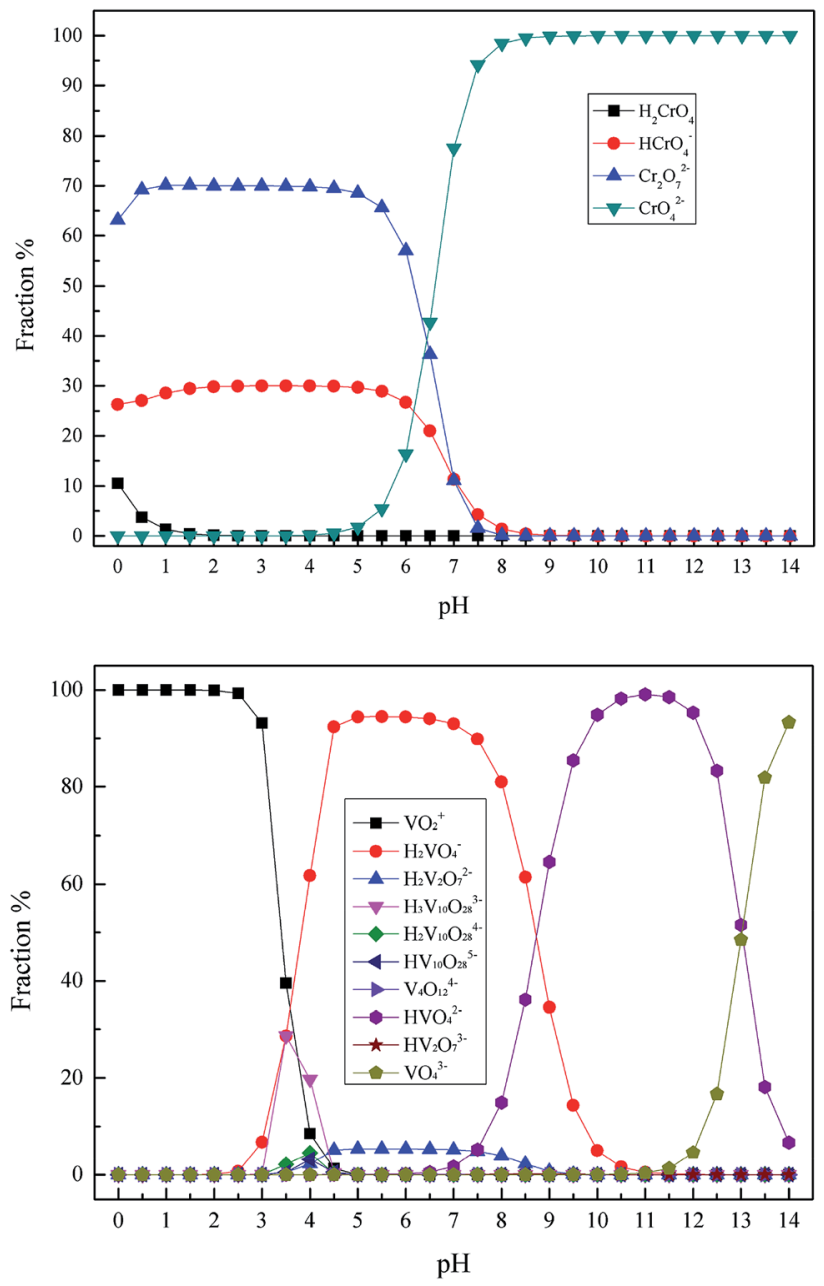

Fig. 2 The species distribution of $\mathrm{Cr}(\mathrm{v})$ and $\mathrm{V}(\mathrm{V})$ in aqueous solutions.

sediment including vanadium and chromium hydroxides and struvite in alkaline conditions, as shown in eqn (5)-(7). In conclusion, the simultaneous removal of $\mathrm{NH}_{4}-\mathrm{N}$ and heavy metal pollution from vanadium containing industrial wastewater could be realized using wet magnesia FGD residue.

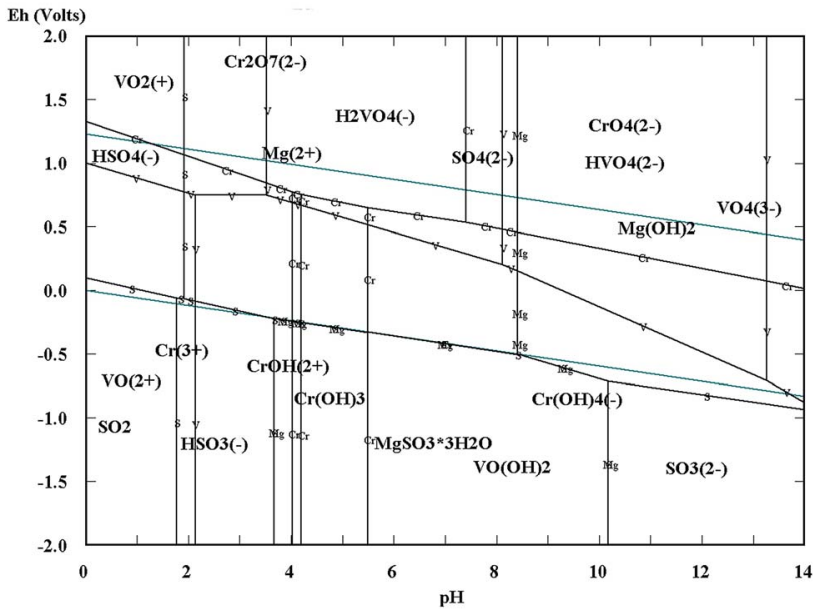

Fig. 3 The Eh-pH diagrams of the $\mathrm{Cr}-\mathrm{V}-\mathrm{S}-\mathrm{Mg}-\mathrm{H}_{2} \mathrm{O}$ system.

$$
\begin{gathered}
\mathrm{MgSO}_{3} \cdot 3 \mathrm{H}_{2} \mathrm{O}+\mathrm{H}^{+} \rightarrow \mathrm{Mg}^{2+}+\mathrm{HSO}_{4}^{-}+3 \mathrm{H}_{2} \mathrm{O} \\
2 \mathrm{VO}_{2}^{+}+\mathrm{HSO}_{3}^{-}+\mathrm{H}^{+} \rightarrow 2 \mathrm{VO}^{2+}+\mathrm{SO}_{4}^{2-}+\mathrm{H}_{2} \mathrm{O} \\
\mathrm{Cr}_{2} \mathrm{O}_{7}^{2-}+3 \mathrm{HSO}_{3}{ }^{-}+5 \mathrm{H}^{+} \rightarrow 2 \mathrm{Cr}^{3+}+3 \mathrm{SO}_{4}^{2-}+4 \mathrm{H}_{2} \mathrm{O} \\
\mathrm{MgCO}_{3}+2 \mathrm{H}^{+} \rightarrow \mathrm{Mg}^{2+}+\mathrm{CO}_{2} \uparrow+\mathrm{H}_{2} \mathrm{O} \\
\mathrm{Cr}^{3+}+3 \mathrm{OH}^{-} \rightarrow \mathrm{Cr}(\mathrm{OH})_{3} \downarrow \\
\mathrm{VO}^{2+}+2 \mathrm{OH}^{-} \rightarrow \mathrm{VO}(\mathrm{OH})_{2} \downarrow \\
\mathrm{Mg}^{2+}+\mathrm{NH}_{4}^{+}+\mathrm{HPO}_{4}{ }^{2-}+6 \mathrm{H}_{2} \mathrm{O} \\
\rightarrow \mathrm{MgNH}_{4} \mathrm{PO}_{4} \cdot 6 \mathrm{H}_{2} \mathrm{O} \downarrow+\mathrm{H}^{+}
\end{gathered}
$$

\section{The optimum $\mathrm{pH}$ of the $\mathrm{Cr}(\mathrm{vI})$ and $\mathrm{V}(\mathrm{v})$ reduction}

According to the reductive mechanism of $\mathrm{Cr}(\mathrm{VI})$ and $\mathrm{V}(\mathrm{v})$, the reductive reaction $\mathrm{pH}$ is an important factor to ensure that the $\mathrm{Cr}(\mathrm{vI})$ and $\mathrm{V}(\mathrm{v})$ could be reduced adequately and rapidly. This experiment was used to determine the optimum $\mathrm{pH}$ within the range from 1.5 to 4.5 , and the wet magnesia FGD residue dosage was $8.5 \mathrm{~g}$, and reaction time was $15 \mathrm{~min}$.

As shown in Fig. 4, the degree of reduction of $\mathrm{Cr}(\mathrm{vI})$ and $\mathrm{V}(\mathrm{v})$ is closely related to the $\mathrm{pH}$. Together with an increase of $\mathrm{pH}$ from 1.5 to 4.5 , the reduction efficiencies of $\mathrm{Cr}(\mathrm{vI})$ and $\mathrm{V}(\mathrm{v})$ reduced from $99.99 \%$ and $99.95 \%$ to $98.74 \%$ and $99.36 \%$, respectively, and the residual $\mathrm{Cr}(\mathrm{vI})$ and $\mathrm{V}(\mathrm{v})$ increased from $0.041 \mathrm{mg} \mathrm{L}^{-1}$ and $0.035 \mathrm{mg} \mathrm{L}^{-1}$ to $47.56 \mathrm{mg} \mathrm{L}^{-1}$ and $0.478 \mathrm{mg} \mathrm{L}^{-1}$, respectively. It is worth noting that the main reduction product of $\mathrm{Cr}(\mathrm{vI})$ was $\mathrm{Cr}^{3+}$ in the $\mathrm{pH}$ range from 2.5 to 4.0 , as shown in eqn (3). Whereas the main reduction products of $\mathrm{Cr}(\mathrm{vI})$ were $\mathrm{Cr}(\mathrm{OH})_{2}{ }^{+}$or $\mathrm{Cr}(\mathrm{OH})_{3}$ in the $\mathrm{pH}$ range from 4.0 to 4.5 , as shown in eqn (8) and (9). The reaction rate of eqn (8) and (9) was slower than that of eqn (3) which resulted in the significant reduction of $\mathrm{Cr}(\mathrm{vI})$ reduction efficiency. In the other words, the low $\mathrm{pH}$ condition was conducive to the reduction of $\mathrm{Cr}(\mathrm{vI})$ and V(v) using wet magnesia FGD residue as a reductant. As required by national Standards, the hazardous heavy metal

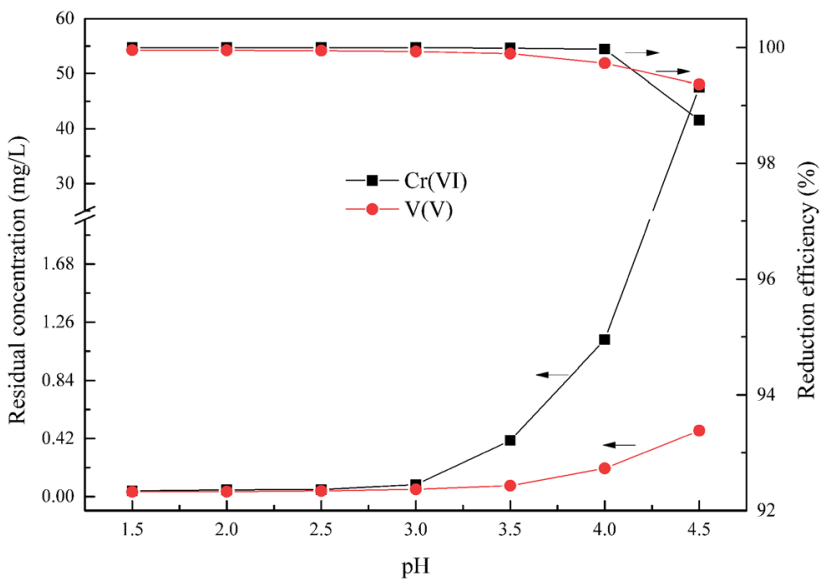

Fig. 4 Effect of $\mathrm{pH}$ on $\mathrm{Cr}(\mathrm{VI})$ and $\mathrm{V}(\mathrm{v})$ reduction. The wet magnesia FGD residue dosage was $8.5 \mathrm{~g}$, and $t=15.0 \mathrm{~min}$. 


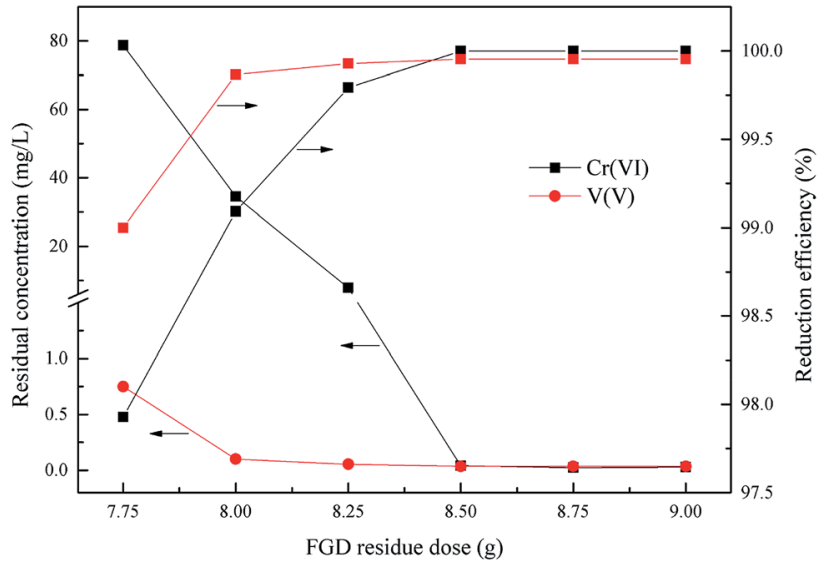

Fig. 5 Effect of wet magnesia FGD dose on $\mathrm{Cr}(\mathrm{VI})$ and $\mathrm{V}(\mathrm{v})$ reduction The optimum $\mathrm{pH}=2.5$, and $t=15.0 \mathrm{~min}$.

pollutants' emission concentration limits of hexavalent chromium and total vanadium were $0.5 \mathrm{mg} \mathrm{L}^{-1}$ and $1.0 \mathrm{mg} \mathrm{L}^{-1}$, respectively. In conclusion, the optimum $\mathrm{pH}$ of the $\mathrm{Cr}(\mathrm{vI})$ and $\mathrm{V}(\mathrm{v})$ reduction process was $\mathrm{pH}=2.5$.

$$
\begin{aligned}
\mathrm{Cr}_{2} \mathrm{O}_{7}{ }^{2-} & +3 \mathrm{MgSO}_{3} \cdot 3 \mathrm{H}_{2} \mathrm{O}+6 \mathrm{H} \rightarrow 2 \mathrm{Cr}(\mathrm{OH})_{2}{ }^{+} \\
& +3 \mathrm{SO}_{4}{ }^{2-}+3 \mathrm{Mg}^{2+}+11 \mathrm{H}_{2} \mathrm{O} \\
\mathrm{Cr}_{2} \mathrm{O}_{7}{ }^{2-} & +3 \mathrm{MgSO}_{3} \cdot 3 \mathrm{H}_{2} \mathrm{O}+2 \mathrm{H}^{+} \rightarrow 2 \mathrm{Cr}(\mathrm{OH})_{3} \\
& +3 \mathrm{SO}_{4}{ }^{2-}+3 \mathrm{Mg}^{2+}+7 \mathrm{H}_{2} \mathrm{O}
\end{aligned}
$$

The optimum wet magnesia FGD residue dose for $\mathrm{Cr}(\mathrm{vI})$ and $\mathrm{V}(\mathrm{v})$ reduction

As is already known, the dose of the reducing agent is a key factor of the redox reaction between $\operatorname{Cr}(\mathrm{vI}), \mathrm{V}(\mathrm{v})$ and the wet magnesia FGD residue. This experiment was done to determine the wet magnesia FGD residue dosage within the range from $7.75 \mathrm{~g}$ to $9.0 \mathrm{~g}$ in $200 \mathrm{~mL}$ of wastewater, the optimum reduction $\mathrm{pH}$ was 2.5 , and the reduction reaction time was $15 \mathrm{~min}$.

As shown in Fig. 5, the degree of reduction of $\operatorname{Cr}(\mathrm{vI})$ and $\mathrm{V}(\mathrm{v})$ was closely related to the dose of wet magnesia FGD residue. With an increase of the wet magnesia FGD residue dose from $7.75 \mathrm{~g}$ to $9.0 \mathrm{~g}$, the reduction efficiency of $\mathrm{Cr}(\mathrm{vI})$ and $\mathrm{V}(\mathrm{v})$ also increased from $97.92 \%$ and $99.0 \%$ to $99.99 \%$ and $99.95 \%$, respectively, and the residual $\mathrm{Cr}(\mathrm{vI})$ and $\mathrm{V}(\mathrm{v})$ reduced from $78.7 \mathrm{mg} \mathrm{L}^{-1}$ and $0.75 \mathrm{mg} \mathrm{L}^{-1}$ to $0.029 \mathrm{mg} \mathrm{L}^{-1}$ and $0.035 \mathrm{mg} \mathrm{L}^{-1}$, respectively. Once the dose of wet magnesia FGD residue reached $8.5 \mathrm{~g}$, the reduction efficiency of $\mathrm{Cr}(\mathrm{vI})$ and $\mathrm{V}(\mathrm{v})$ was steady and the residual pollutant concentration was far below the emission concentration limits. Consequently, the optimum wet magnesia FGD residue dose for $\mathrm{Cr}(\mathrm{v})$ and $\mathrm{V}(\mathrm{v})$ reduction was $8.5 \mathrm{~g}\left(42.5 \mathrm{~g} \mathrm{~L}^{-1}\right)$.

\section{The optimum time for $\mathrm{Cr}(\mathrm{v})$ and $\mathrm{V}(\mathrm{v})$ reduction}

This experiment was carried out to determine the optimum time of $\mathrm{Cr}(\mathrm{vI})$ and $\mathrm{V}(\mathrm{v})$ reduction within the range of reaction time from $5.0 \mathrm{~min}$ to $30.0 \mathrm{~min}$, the optimum reduction $\mathrm{pH}=$ 2.5 , the optimum wet magnesia FGD residue dose was $8.5 \mathrm{~g}$ in $200 \mathrm{~mL}$ of wastewater.

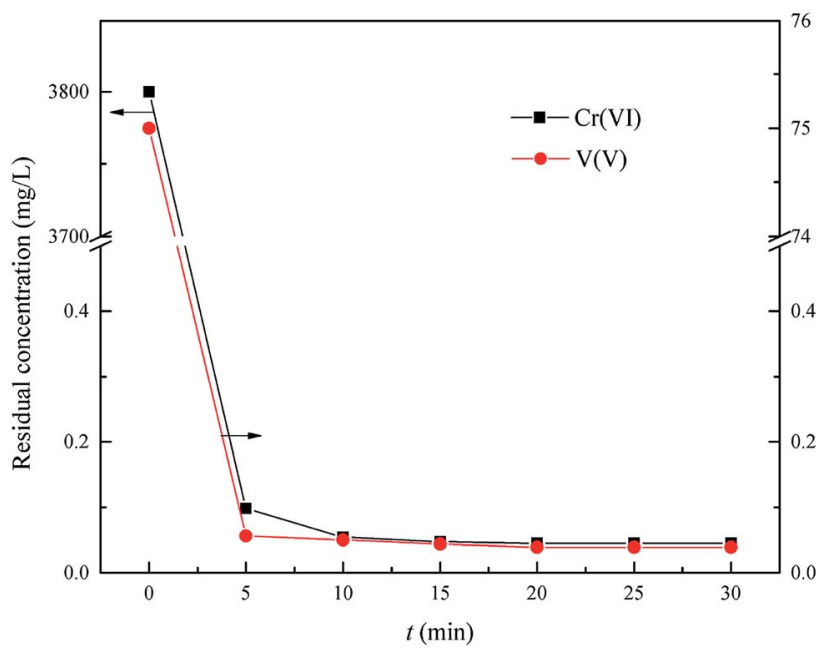

Fig. 6 Effect of reaction time on $\mathrm{Cr}(\mathrm{VI})$ and $\mathrm{V}(\mathrm{v})$ reduction. The optimum $\mathrm{pH}$ is 2.5 , and the wet magnesia FGD residue dose is $8.5 \mathrm{~g}$.

As shown in Fig. 6, the residual $\mathrm{Cr}(\mathrm{vI})$ and $\mathrm{V}(\mathrm{v})$ reduced significantly from the initial $3800 \mathrm{mg} \mathrm{L}^{-1}$ and $75 \mathrm{mg} \mathrm{L}^{-1}$ to $0.045 \mathrm{mg} \mathrm{L}^{-1}$ and $0.039 \mathrm{mg} \mathrm{L}^{-1}$, respectively, with an increase of reduction time from $0 \mathrm{~min}$ to $30.0 \mathrm{~min}$, respectively. Therefore, the $\mathrm{Cr}(\mathrm{VI})$ and $\mathrm{V}$ (v) could be reduced quickly to $\mathrm{Cr}(\mathrm{III})$ and $\mathrm{V}$ (IV) by using the wet magnesia FGD residue as a reductant within $15.0 \mathrm{~min}$. So, the wet magnesia FGD residue could be regarded as a low cost and environmentally effective substitute for conventional reductants, such as sodium metabisulfite $\left(\mathrm{Na}_{2} \mathrm{~S}_{2} \mathrm{O}_{5}\right)$ or iron(II) sulfate $\left(\mathrm{FeSO}_{4}\right)$. Consequently, the optimum reduction time was $15.0 \mathrm{~min}$, and the concentration of the by-product, magnesium ions was about $5517 \mathrm{mg} \mathrm{L}^{-1}$.

\section{The optimum pH for ammonium nitrogen and heavy metal pollutants removal}

The $\mathrm{pH}$ was a key factor for struvite crystallization and the formation of chromium and vanadium hydroxides. This experiment was performed to determine the optimum $\mathrm{pH}$ of total chromium, vanadium and ammonium removal within the

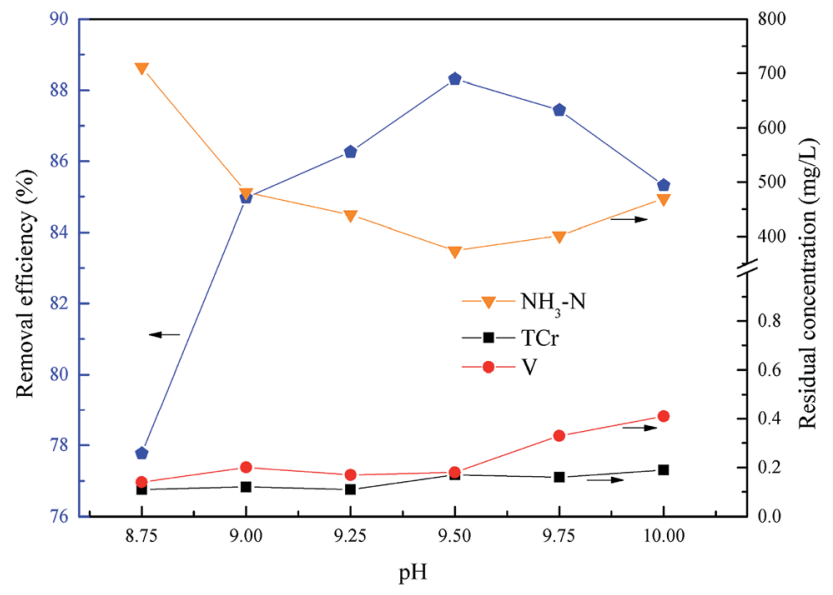

Fig. 7 Effect of $\mathrm{pH}$ on $\mathrm{NH}_{4}-\mathrm{N}$ and heavy metal pollutants removal. The molar ratio $n\left(\mathrm{Mg}^{2+}\right): n\left(\mathrm{NH}_{4}{ }^{+}\right): n\left(\mathrm{PO}_{4}{ }^{3-}\right)=0: 1.0: 1.0$, and $t=$ $15.0 \mathrm{~min}$ 
$\mathrm{pH}$ range 8.75 to 10.0 , with the molar ratio of $n\left(\mathrm{Mg}^{2+}\right): n\left(\mathrm{NH}_{4}{ }^{+}\right): n\left(\mathrm{PO}_{4}{ }^{3-}\right)=1.0: 1.0: 1.0$, and the reaction time was $15.0 \mathrm{~min}$. The molar ratio of the residual $\mathrm{Mg}^{2+}$ $\left(5517 \mathrm{mg} \mathrm{L}^{-1}\right.$ ) and $\mathrm{NH}_{4}{ }^{+}$was about $1.0: 1.0$, so the actual added molar ratio of $n\left(\mathrm{Mg}^{2+}\right): n\left(\mathrm{NH}_{4}{ }^{+}\right): n\left(\mathrm{PO}_{4}{ }^{3-}\right)$ was $0: 1.0: 1.0$.

As shown in Fig. 7, the removal efficiency of ammonium increased first from $77.77 \%$ to $88.31 \%$ and then reduced to $85.32 \%$ with an increase of $\mathrm{pH}$, and the ammonium removal efficiency reached a peak at $\mathrm{pH}=9.5$, and the residual concentrations of chromium and vanadium were always below the emission concentration limits. The main form of phosphate was $\mathrm{HPO}_{4}{ }^{2-}$ in alkaline conditions within the experimental $\mathrm{pH}$ range. As shown in eqn (7), the excess $\mathrm{H}^{+}$would inhibit the formation of struvite. With the $\mathrm{pH}$ increasing, more $\mathrm{PO}_{4}{ }^{3-}$ was dissociated from $\mathrm{HPO}_{4}{ }^{2-}$ which lead to the struvite being replaced by magnesium phosphate $\left[\mathrm{Mg}_{3}\left(\mathrm{PO}_{4}\right)_{2}\right] \cdot{ }^{34-36}$ Consequently, the optimum $\mathrm{pH}$ of total chromium, vanadium and ammonium removal was 9.5.

\section{The optimum molar ratio of $n\left(\mathrm{Mg}^{2+}\right): n\left(\mathrm{NH}_{4}{ }^{+}\right): n\left(\mathrm{PO}_{4}{ }^{3-}\right)$ for $\mathrm{NH}_{4}-\mathrm{N}$ removal}

This experiment was used to determine the optimum molar ratio $n\left(\mathrm{Mg}^{2+}\right): n\left(\mathrm{NH}_{4}{ }^{+}\right): n\left(\mathrm{PO}_{4}{ }^{3-}\right)$ for $\mathrm{NH}_{4}-\mathrm{N}$ removal within
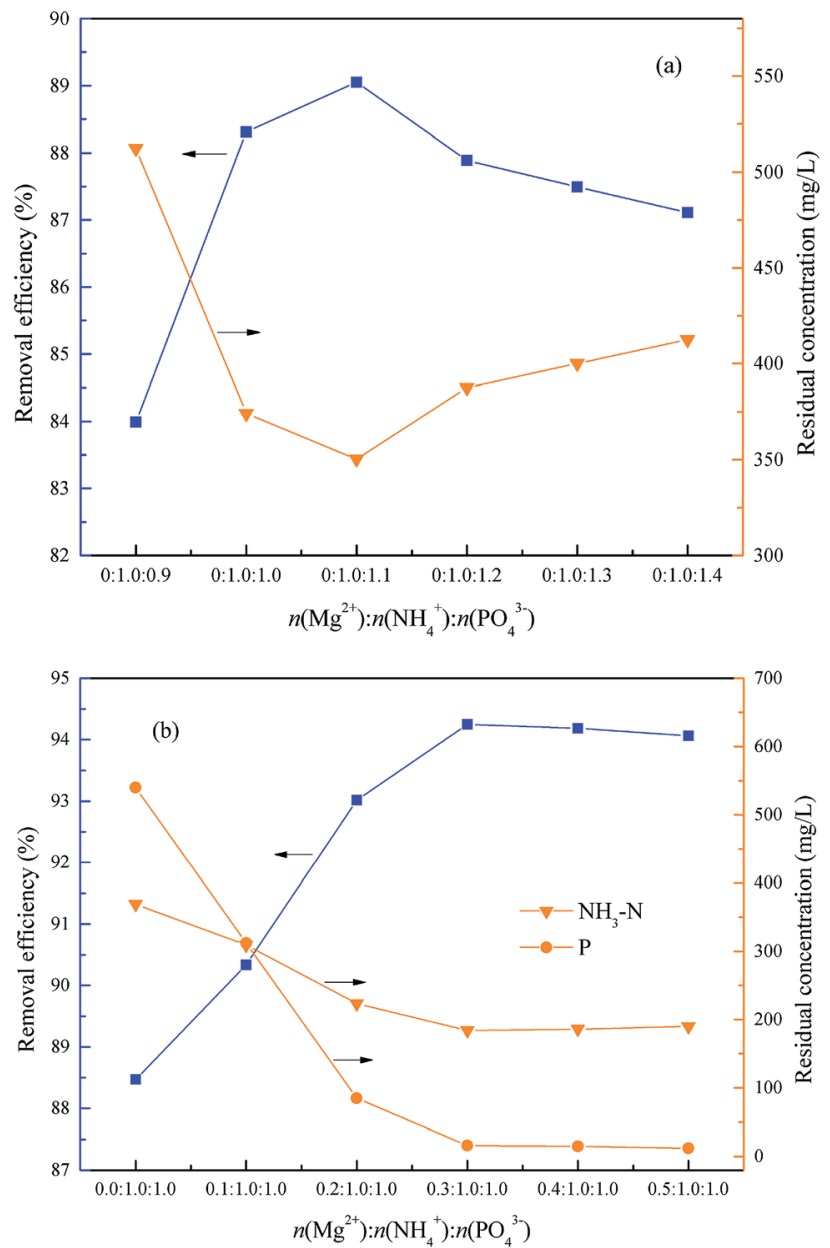

Fig. 8 Effect of the molar ratio $n\left(\mathrm{Mg}^{2+}\right): n\left(\mathrm{NH}_{4}{ }^{+}\right): n\left(\mathrm{PO}_{4}{ }^{3-}\right)$ on $\mathrm{NH}_{4}-$ $\mathrm{N}$ removal. The optimum $\mathrm{pH}=9.5$ and $t=15 \mathrm{~min}$.
15.0 min. Firstly, the optimum molar ratio between $\mathrm{NH}_{4}{ }^{+}$and $\mathrm{PO}_{4}{ }^{3-}$ was investigated within the range of $n\left(\mathrm{Mg}^{2+}\right): n\left(\mathrm{NH}_{4}{ }^{+}\right): n\left(\mathrm{PO}_{4}{ }^{3-}\right)=0: 1.0: 0.9$ to $0: 1.0: 1.4$, and the optimum $\mathrm{pH}=9.5$. As shown in Fig. 8(a), the removal rate of $\mathrm{NH}_{4}-\mathrm{N}$ increased first from $83.99 \%$ to $89.05 \%$ and then reduced slightly to $87.10 \%$ together with an increase of the molar ratio $n\left(\mathrm{Mg}^{2+}\right): n\left(\mathrm{NH}_{4}{ }^{+}\right): n\left(\mathrm{PO}_{4}{ }^{3-}\right)$ from $0: 1.0: 0.9$ to $0: 1.0: 1.4$. Consequently, the optimum molar ratio between $\mathrm{NH}_{4}{ }^{+}$and $\mathrm{PO}_{4}{ }^{3-}$ was $1.0: 1.0$ because the excess $\mathrm{PO}_{4}{ }^{3-}$ lead to a phosphorus residue with only a little increase of $\mathrm{NH}_{4}-\mathrm{N}$ removal.

Subsequently, the optimum molar ratio between $\mathrm{Mg}^{2+}$ and $\mathrm{NH}_{4}{ }^{+}$was investigated within the range of $n\left(\mathrm{Mg}^{2+}\right): n\left(\mathrm{NH}_{4}{ }^{+}\right): n\left(\mathrm{PO}_{4}{ }^{3-}\right)=0: 1.0: 1.0-0.5: 1.0: 1.0$, and the optimum $\mathrm{pH}=9.5$. As shown in Fig. 8(b), with an increase of molar ratio of $n\left(\mathrm{Mg}^{2+}\right): n\left(\mathrm{NH}_{4}{ }^{+}\right): n\left(\mathrm{PO}_{4}{ }^{3-}\right)$ from $0: 1.0: 1.0$ to $0.5: 1.0: 1.0$, the $\mathrm{NH}_{4}-\mathrm{N}$ removal rate increased first from $88.46 \%$ to $94.25 \%$ and then reduced slightly to $94.06 \%$, and the residual phosphorus was also reduced markedly from $540 \mathrm{mg} \mathrm{L}^{-1}$ to $12.0 \mathrm{mg} \mathrm{L}^{-1}$. Consequently, the optimum molar ratio of $n\left(\mathrm{Mg}^{2+}\right): n\left(\mathrm{NH}_{4}^{+}\right)$was $0.3: 1.0$.

It is worth noting that the serious overdosing of $\mathrm{Mg}^{2+}$ or $\mathrm{HPO}_{4}{ }^{2-}$ would reduce the ammonium removal efficiency, because the concentration of $\mathrm{PO}_{4}{ }^{3-}$ would be increased together with the $\mathrm{HPO}_{4}{ }^{2-}$ increasing because of the dissociation of $\mathrm{HPO}_{4}{ }^{2-}$, as shown in eqn (10). So, excessive $\mathrm{PO}_{4}{ }^{3-}$ could be consumed before more $\mathrm{Mg}^{2+}$ to produce $\mathrm{Mg}_{3}\left(\mathrm{PO}_{4}\right)_{2}$ which would result in a shortage of $\mathrm{Mg}^{2+}$ to form struvite, as shown in eqn (11). Also, excessive $\mathrm{Mg}^{2+}$ would also consume more $\mathrm{PO}_{4}{ }^{3-}$ to produce $\mathrm{Mg}_{3}\left(\mathrm{PO}_{4}\right)_{2}$ which would result in the shortage of $\mathrm{HPO}_{4}{ }^{2-}$ to form struvite. ${ }^{7,33,34}$ Consequently, the optimum molar ratio of $n\left(\mathrm{Mg}^{2+}\right): n\left(\mathrm{NH}_{4}{ }^{+}\right): n\left(\mathrm{PO}_{4}{ }^{3-}\right)=0.3: 1.0: 1.0$.

$$
\begin{gathered}
\mathrm{HPO}_{4}{ }^{2-} \rightarrow \mathrm{H}^{+}+\mathrm{PO}_{4}^{3-} \\
\mathrm{Mg}^{2+}+\mathrm{PO}_{4}{ }^{3-} \rightarrow \mathrm{Mg}_{3}\left(\mathrm{PO}_{4}\right)_{2}
\end{gathered}
$$

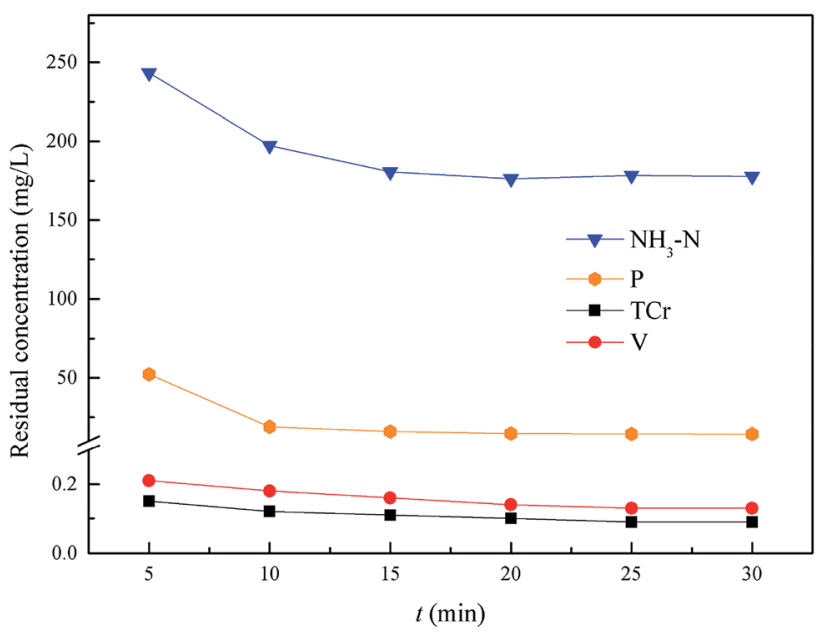

Fig. 9 Effect of $\mathrm{NH}_{4}-\mathrm{N}$ and heavy metal pollutant removal. The optimum $\mathrm{pH}=9.5$, and the molar ratio $n\left(\mathrm{Mg}^{2+}\right): n\left(\mathrm{NH}_{4}^{+}\right): n\left(\mathrm{PO}_{4}{ }^{3-}\right)=$ $0.3: 1.0: 1.0$ 

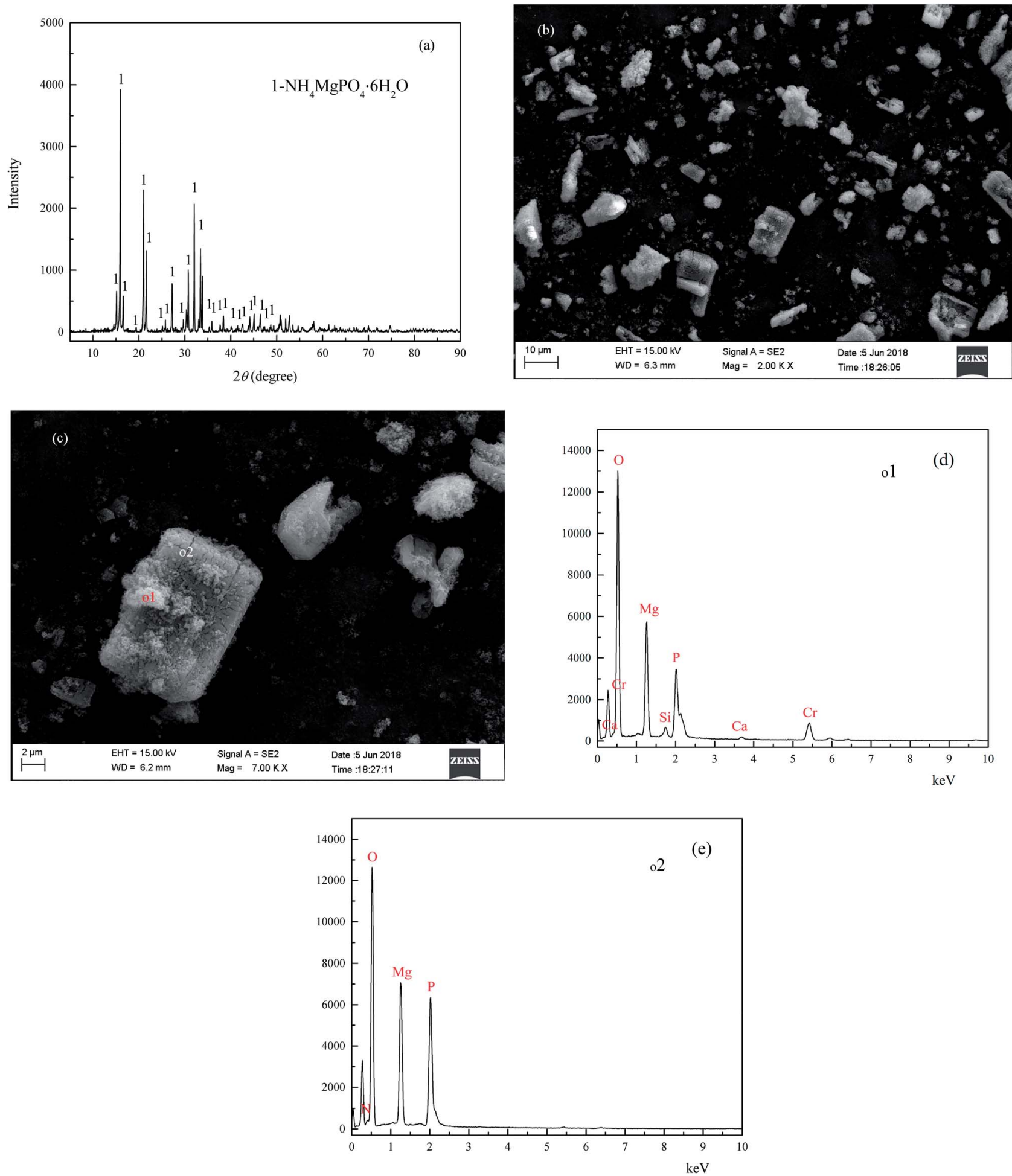

Fig. 10 XRD pattern (a), SEM (b and c) EDS patterns ( $d$ and e) of the coprecipitate.

The optimum reaction time for $\mathrm{NH}_{4}-\mathrm{N}$ and heavy metal pollutant removal

This experiment was used to determine the optimum reaction time of $\mathrm{NH}_{4}-\mathrm{N}$ and heavy metal pollutants from $5.0 \mathrm{~min}$ to $30.0 \mathrm{~min}$, with an optimum $\mathrm{pH}=9.5$, and the optimum molar ratio $n\left(\mathrm{Mg}^{2+}\right): n\left(\mathrm{NH}_{4}{ }^{+}\right): n\left(\mathrm{PO}_{4}{ }^{3-}\right)=0.3: 1.0: 1.0$. As shown in Fig. 9, the residual $\mathrm{NH}_{4}-\mathrm{N}$ and heavy metal pollutants could reach an optimal state and remain stable within $20.0 \mathrm{~min}$. So, the optimum reaction time of $\mathrm{NH}_{4}-\mathrm{N}$ and heavy metal pollutants removal was $20.0 \mathrm{~min}$, and the residual pollutant levels were: $\mathrm{Cr}(\mathrm{vI}): 0.047 \mathrm{mg} \mathrm{L}^{-1}$, total Cr: $0.1 \mathrm{mg} \mathrm{L}^{-1}$, V: $0.14 \mathrm{mg} \mathrm{L}^{-1}, \mathrm{NH}_{4}-\mathrm{N}$ : 
$176.2 \mathrm{mg} \mathrm{L}^{-1}$ (removal efficiency was $94.5 \%$ ) and phosphorus: $14.7 \mathrm{mg} \mathrm{L}^{-1}$.

\section{Characterization analysis of the coprecipitate}

The XRD analysis results of the coprecipitate are shown in Fig. 10(a), and the main peaks of the coprecipitate are entirely consistent with $\mathrm{MgNH}_{4} \mathrm{PO}_{4} \cdot 6 \mathrm{H}_{2} \mathrm{O}$ (struvite JCPDS no. 01-0772303). The micrographs of the coprecipitate are shown in Fig. 10(b) and (c), and show some irregular agglomerated particles attached to the surface of the bulk shape crystal. The EDS patterns of the coprecipitate are shown in Fig. 10(d) and (e), and the main chemical element constituent of the bulk shape crystal [o2, Fig. 10(e)] contained O, Mg, N, P, which is consistent with the element constituents of struvite. In comparison, the chemical element constituent of irregular agglomerated particles [01, Fig. 10(d)] on the surface of the bulk shape crystal contained $\mathrm{O}, \mathrm{Mg}, \mathrm{P}, \mathrm{Cr}, \mathrm{Ca}$ and $\mathrm{Si}$. The results of the quantitative analysis of the coprecipitate was (wt\%): MgO: 17.45, P: 10.32, chromium(III) oxide $\left(\mathrm{Cr}_{2} \mathrm{O}_{3}\right)$ : 8.27, N: 4.17, Na: 0.29, S: 0.165, V: 0.14, CaO: 0.47, $\mathrm{SiO}_{2}: 1.11$, and TFe: 0.24 . In conclusion, the heavy metal pollutants and $\mathrm{NH}_{4}-\mathrm{N}$ in the vanadium containing industrial wastewater were removed by forming the difficult to obtain, soluble coprecipitate containing struvite and chromium and vanadium hydroxide in alkaline conditions.

\section{Conclusions}

In this paper, a novel resource utilization method of the wet magnesia flue gas desulfurization residue for simultaneously removing ammonium nitrogen and heavy metal pollutants from vanadium containing industrial wastewater was proven to be viable and effective. The main mineral phases of the wet magnesia flue gas desulfurization residue were $\mathrm{MgSO}_{3} \cdot 3 \mathrm{H}_{2} \mathrm{O}$ and $\mathrm{MgCO}_{3}$ with a minor amount of $\mathrm{MgSO}_{4} \cdot 7 \mathrm{H}_{2} \mathrm{O}$ and $\mathrm{MgSO}_{4} \cdot 4 \mathrm{H}_{2} \mathrm{O}$. The optimum experimental conditions of hexavalent chromium and pentavalent vanadium reduction were: the reduction $\mathrm{pH}=2.5$, wet magnesia flue gas desulfurization dose was $42.5 \mathrm{~g} \mathrm{~L}^{-1}$, and the reduction time was $15.0 \mathrm{~min}$. The optimum experimental conditions of ammonium nitrogen and heavy metal pollutants removal were: the precipitate reaction $\mathrm{pH}=9.5$, the molar ratio $n\left(\mathrm{Mg}^{2+}\right): n\left(\mathrm{NH}_{4}{ }^{+}\right): n\left(\mathrm{PO}_{4}{ }^{3-}\right)$ $=0.3: 1.0: 1.0$, and the reaction time was $20.0 \mathrm{~min}$. The residual pollutant concentrations were: chromium(vI) was $0.047 \mathrm{mg} \mathrm{L}^{-1}$, total chromium was $0.1 \mathrm{mg} \mathrm{L}^{-1}$, vanadium was $0.14 \mathrm{mg} \mathrm{L}^{-1}$, ammonium nitrogen was $176.2 \mathrm{mg} \mathrm{L}^{-1}$ (removal efficiency was $94.5 \%$ ) and phosphorus was $14.7 \mathrm{mg} \mathrm{L}^{-1}$. The main pollutants in the vanadium containing industrial wastewater could be removed by forming the difficult to obtain, soluble coprecipitate containing struvite, chromium and vanadium hydroxide.

In general, this research provided a relatively low cost, efficient and environmental treatment process of the vanadium containing industrial wastewater and wet magnesia FGD residue, which has realized the objective of "waste treated using waste".

\section{Conflicts of interest}

There are no conflicts of interest to declare.

\section{Acknowledgements}

The authors are grateful for the support from the Natural Science Foundation of China (No. U1502273).

\section{References}

1 H. Zhang, B. Zhang and J. Bi, Energy, 2015, 80, 1-9.

2 T. Zhu, Y. Ma, H. Zhang, D. Li and L. Li, Catal. Today, 2015, 258, 70-74.

3 X. Liu, B. Lin and Y. Zhang, J. Cleaner Prod., 2016, 113, 133143.

4 F. J. Gutiérrez Ortiz, Chem. Eng. J., 2010, 165, 426-439.

5 D. Fang, X. Liao, X. Zhang, A. Teng and X. Xue, J. Hazard. Mater., 2017, 342, 436-445.

6 D. Zheng, H. Lu, X. Sun, X. Liu, W. Han and L. Wang, Thermochim. Acta, 2013, 559, 23-31.

7 D. Fang, X. Zhang, M. Dong and X. Xue, J. Hazard. Mater., 2017, 336, 8-20.

8 Z. Shen, X. Chen, M. Tong, S. Guo, M. Ni and J. Lu, Fuel, 2013, 105, 578-584.

9 L. Wang, Y. Ma, W. Zhang, Q. Li, Y. Zhao and Z. Zhao, J. Hazard. Mater., 2013, 258-259, 61-69.

10 R. Guo, W. Pan, X. Zhang, H. Xu and J. Ren, Fuel, 2011, 90, 710.

11 R. Valle-Zermeño, J. Formosa, J. Aparicio and J. Chimenos, Chem. Eng. J., 2014, 254, 63-72.

12 L. Wang, S. Cui, Q. Li, J. Wang and S. Liu, Appl. Catal., A, 2016, 511, 16-22.

13 Q. Li, Y. Yang, L. Wang, P. Xu and Y. Han, Appl. Catal., B, 2017, 203, 851-858.

14 L. Guo, W. Liu, X. Tang, H. Wang, Q. Liu and Y. Zhu, Chem. Eng. J., 2017, 330, 870-879.

15 L. Yan, X. Lu, Q. Guo, Q. Wang and X. Ji, Adv. Powder Technol., 2014, 25, 1709-1714.

16 L. Yan, X. Lu, Q. Wang, Y. Kang, J. Xu and Y. Chen, Therm. Eng., 2014, 65, 487-494.

17 Y. Zhang, S. Bao, T. Liu, T. Chen and J. Huang, Hydrometallurgy, 2011, 109, 116-124.

18 R. R. Moskalyk and A. M. Alfantazi, Miner. Eng., 2003, 16, 793-805.

19 X. Zhang, F. Liu, X. Xue and T. Jiang, J. Alloys Compd., 2016, 686, 356-365.

20 M. R. Tavakoli, S. Dornian and D. B. Dreisinger, Hydrometallurgy, 2014, 141, 59-66.

21 H. Li, H. Fang, K. Wang, W. Zhou, Z. Yang, X. Yan, W. Ge, Q. Li and B. Xie, Hydrometallurgy, 2015, 156, 12-135.

22 D. He, Q. Feng, G. Zhang, L. Ou and Y. Lu, Miner. Eng., 2007, 20, 1184-1186.

23 K. Yang, X. Zhang, X. Tian, Y. Yang and Y. Chen, Hydrometallurgy, 2010, 103, 7-11.

24 X. Li, B. Xie, G. Wang and X. Li, Trans. Nonferrous Met. Soc. China, 2011, 21, 1860-1867. 
25 Y. Ji, S. Shen, J. Liu and Y. Xue, J. Cleaner Prod., 2017, 149, 1068-1078.

26 C. Barreradíaz, V. Lugolugo and B. Bilyeu, J. Hazard. Mater., 2012, 223-224, 1-12.

27 S. Wilson and J. Weber, Chem. Geol., 1979, 26, 345-354.

28 B. Wehrli and W. Stumm, Geochim. Cosmochim. Acta, 1989, 53, 69-77.

29 J. A. Dean, Lange's Handbook of Chemistry, McGraw-Hill, New York, 1999.

30 S. Xu, S. Pan, Y. Xu, Y. Luo, Y. Zhang and G. Li, J. Hazard. Mater., 2015, 283, 7-13.
31 Y. Yuan, S. Yang, D. Zhou and F. Wu, J. Hazard. Mater., 2016, 307, 294-301.

32 D. Zhang, Y. Chen, G. Jilani, W. Wu, W. Liu and Z. Han, Bioresour. Technol., 2012, 116, 386-395.

33 T. Zhang, L. Ding, H. Ren and X. Xiong, Water Res., 2009, 43, 5209-5215.

34 T. Zhang, L. Ding and H. Ren, J. Hazard. Mater., 2009, 166, 911-915.

35 H. Huang, D. Xiao, Q. Zhang and L. Ding, J. Environ. Manage., 2014, 145, 191-198.

36 S. Zhou and Y. Wu, Environ. Sci. Pollut. Res. Int., 2012, 19, 347-360. 